ALCHEMY Jurnal Penelitian Kimia

Laman resmi: https://jurnal.uns.ac.id/alchemy

\title{
Aktivitas Antibakteri dan Antioksidan Asam Galat dari Kulit Buah Lokal yang Diproduksi dengan Tanase
}

\author{
Eka Junaidi ${ }^{a}$, Yunita Arian Sani Anwar ${ }^{a^{*}}$ \\ ${ }^{a}$ Program Studi Pendidikan Kimia, Fakultas Keguruan dan Ilmu Pendidikan, Universitas Mataram, Jl. \\ Majapahit 62 Mataram, Indonesia \\ * Corresponding author \\ E-mail: riananwar04@gmail.com
}

DOI: 10.20961/alchemy.14.1.11300.131-142

Received 23 May 2017, Accepted 23 July 2017, Published 1 March 2018

\begin{abstract}
ABSTRAK
Penelitian ini mempelajari tentang produksi asam galat menggunakan enzim tanase dari limbah kulit buah lokal di Lombok. Limbah kulit buah lokal yang digunakan yaitu kulit buah kepundung (Baccaurea racemosa Muell.Arg), kulit buah juwet (Syzygium cumini), dan kulit buah manggis (Garcinia mangostana). Pada penelitian ini dilakukan pengujian asam galat yang dihasilkan, untuk mengetahui aktivitas antioksidan dan antibakteri. Pengujian sifat antioksidan dilakukan dengan menggunakan metode DPPH, sedangkan aktivitas antibakteri diuji dengan menggunakan metode difusi agar pada bakteri Escherichia coli dan Staphylococcus aureus. Hasil penelitian menunjukkan bahwa asam galat dari ketiga kulit buah memiliki aktivitas antioksidan. Asam galat dari kulit buah kepundung, kulit buah juwet dan kulit buah manggis memiliki $\mathrm{IC}_{50}$ masing-masing sebesar 5.95; 5,96; dan 5,92 ppm. Berbeda dengan kemampuan sebagai antioksidan, asam galat resistan terhadap bakteri Escherichia coli dan Staphylococcus aureus yang menunjukkan bahwa asam galat tidak memiliki aktivitas sebagai antibakteri.
\end{abstract}

Kata kunci: antibakteri, antioksidan, asam galat, kulit buah lokal

\begin{abstract}
Antibacterial and Antioxidant Activity of Gallic Acid Extracted from Local Fruit Peels Produced by Tannase. This research studied the gallic acid production using tannase enzym from fruit local peels in Lombok. The local fruit waste used are kepundung rind (Baccaurea racemosa Muell.Arg), juwet rind (Syzygium cumini) and mangosteen rind (Garcinia mangostana). The produced Gallic acid was tested to determine its antioxidant and antibacterial activity. The antioxidant test conducted by DPPH method, meanwhile, the antibacterial activity was performed by agar diffusion method against bacteria Escherichia coli and Staphylococcus aureus. The results showed that the produce gallic acid from those three rind provide antioxidant activity. Gallic acid from kepundung rind, juwet rind, and mangosteen rind have $\mathrm{IC}_{50}$ values of 5,95; 5,96; and 5,92, respectively. Gallic acid does not showed inhibitory actions against the growth of Escherichia coli and Staphylococcus aureus. This result showed that gallic acid from local fruit waste provided no an antibacterial activity.
\end{abstract}

Keywords: antibacterial, antioxidant, gallic acid, peel local fruit 


\section{PENDAHULUAN}

Buah lokal di Pulau Lombok saat ini kurang popular dan hanya bersifat limbah. Padahal sejak dahulu masyarakat telah banyak memanfaatkan tanaman lokal sebagai bahan baku obat di antaranya sebagai obat diare dan peluruh haid. Kemampuan tanaman sebagai obat dipengaruhi oleh kandungan metabolit sekunder sebagai senyawa aktif yang ada di dalamnya (Gaffar et al., 2008; Pedraza-Chaverri, 2008).

Asam galat merupakan salah satu senyawa aktif yang banyak dimanfaatkan di bidang medis. Senyawa ini terdapat sebagai metabolit sekunder pada tanaman (Vazirian et al., 2011). Keberadaan asam galat dalam tanaman terdapat pada konsentrasi yang kecil. Asam galat dapat bergabung dengan glukosa membentuk tanin terhidrolisis (Hagerman, 2002). Asam galat memiliki aktivitas sebagai antibakteri, antivirus, analgesik dan antioksidan (Belur and Pallabhanvi, 2011). Nutan et al. (2013) dan Chia et al. (2010) melaporkan bahwa asam galat dapat bertindak sebagai anti HIV dan antikarsinogenik.

Produksi asam galat di industri lebih banyak menggunakan hidrolisis asam. Metode ini memiliki beberapa kekurangan yaitu membutuhkan biaya yang besar, produksi lebih kecil dan penggunaan pelarut yang bersifat asam (Beniwal et al., 2010). Kekurangan metode ini menyebabkan penggunaan enzim dan mikroba menjadi alternatif dalam produksi asam galat (Bajpai and Patil, 2008; Banerjee et al., 2007).

Tanase merupakan enzim yang spesifik memutuskan ikatan ester menghasilkan asam galat. Enzim ini dapat digunakan untuk menghasilkan asam galat melalui reaksi enzimatis tanin (Lokeswari and Kumar, 2013). Tanase dapat dihasilkan dari mikroorganisme seperti bakteri, jamur atau yeast. Aspergillus niger dilaporkan mampu menghasilkan tanase menggunakan media padat (Anwar et al., 2007; Anwar and Burhanuddin, 2012).

Kulit buah kepundung, manggis dan juwet dilaporkan memiliki kandungan senyawa tanin yang tinggi. Dari segi struktur diketahui bahwa tanin terhidrolisis terbentuk dari gabungan glukosa dan asam galat sehingga diasumsikan bahwa kandungan tanin yang tinggi sebanding dengan kandungan asam galat. Hasil penelitian sebelumnya menemukan kulit buah kepundung menghasilkan asam galat yang lebih tinggi dibandingkan buah juwet dan manggis (Junaidi and Anwar, 2015).

Penelitian ini bertujuan untuk mengetahui aktivitas asam galat sebagai antioksidan dan antibakteri dari limbah kulit buah lokal yang diproduksi secara enzimatis dengan tanase. Penelitian ini diharapkan dapat menjadi alternatif produksi asam galat sebagai bahan baku obat dari kulit buah lokal. 


\section{METODE PENELITIAN}

Bahan yang digunakan meliputi Aspergillus niger, medium Czapeck, Tween 80, amonium sulfat (Kanto), larutan Nessler (Merck), asam tanat (Merck), etanol, kulit buah manggis, kulit buah juwet, kulit buah kepundung, metanol, bufer sitrat, etil asetat, asam sulfat, rodanin (Sigma), KOH, asam galat (Sigma), DPPH (Sigma), BHA (Sigma), asam askorbat (Sigma), amoxilin, isolat Escherichia coli dan Staphylococcus aureus. Alat yang digunakan pada penelitian ini adalah inkubator, magnetic stirrer, shaker bath, sentrifuge dingin (Beckman J2-21), spektrofotometerUV-Vis (Genesys 20), autoklaf (American), pH meter, evaporator, cawan petri (pyrex), dan Erlenmeyer (pyrex).

\section{Produksi Enzim Tanase}

Prosedur untuk produksi tanase mengacu pada metode Anwar and Burhanuddin (2012). Sebanyak $5 \mathrm{~g}$ tepung gandum dimasukkan ke dalam Erlenmeyer $125 \mathrm{~mL}$ dan dibasahi dengan $10 \mathrm{~mL}$ medium Czapeck yang mengandung $3 \mathrm{~g} / \mathrm{L} \mathrm{NaNO}_{3} ; 0,5 \mathrm{~g} / \mathrm{L} \mathrm{KCl}$; 0,348 g/L MgSO $4.3 \mathrm{H}_{2} \mathrm{O} ; 0,01 \mathrm{~g} / \mathrm{L} \mathrm{FeSO}_{4} \cdot 7 \mathrm{H}_{2} \mathrm{O} ; 1,301 \mathrm{~g} / \mathrm{L} \mathrm{K}_{2} \mathrm{HPO}_{4} \cdot 3 \mathrm{H}_{2} \mathrm{O}$ pada $\mathrm{pH} 5,5$. Media selanjutnya disterilisasi dengan menggunakan autoklaf pada suhu $121{ }^{\circ} \mathrm{C}$ selama 15 menit. Setelah itu, ke dalam media padat tersebut diinokulasikan $1 \mathrm{~mL}$ spora jamur $A$. niger dan diinkubasi pada suhu kamar selama 3 hari.

Isolasi enzim kasar dilakukan dengan cara mengekstrak media fermentasi dengan menambahkan $50 \mathrm{~mL}$ aquades steril yang mengandung 0,01\% Tween 80. Campuran tersebut dilarutkan dengan menggunakan magnetik stirrer. Enzim kasar (crude enzyme) selanjutnya dipisahkan dari media melalui sentrifugasi. Supernatan disaring dengan kertas Whatman no. 1 dan dimasukkan ke dalam botol.

Enzim kasar difraksinasi dengan amonium sulfat pada tingkat kejenuhan $70 \%$. Perlakuan ini dilakukan pada kondisi suhu $4{ }^{\circ} \mathrm{C}$ selama 3 jam. Pemisahan dilakukan dengan sentrifugasi 7700 g selama 20 menit pada suhu yang sama, kemudian endapan yang diperoleh disuspensikan dalam bufer sitrat $50 \mathrm{mM}$ pH 5,0. Pemekatan enzim dilakukan dengan cara dialisis pada suhu $4{ }^{\circ} \mathrm{C}$ selama semalam dan bufernya dapat diganti beberapa kali sampai cairan diluar selofan tidak bereaksi dengan larutan Nessler.

\section{Produksi Asam Galat dari Ekstrak Buah Lokal}

Limbah buah manggis, juwet dan kepundung disortir dan dikering anginkan. Sampel selanjutnya diektraksi dengan menggunakan metanol. Pelarut diuapkan dengan evaporator. Sebanyak 1 gram ekstrak kering dipanaskan dengan $20 \mathrm{~mL}$ aquades selama 30 menit. Larutan diencerkan dengan aquades hingga volume larutan menjadi $50 \mathrm{~mL}$ dan 
disaring dengan menggunakan kertas Whatman no. 1. Filtrat yang dihasilkan ditambahkan bufer sitrat $0,15 \mathrm{M}$ untuk memperoleh $\mathrm{pH}$ larutan sebesar 6 . Selanjutnya ke dalam filtrat dimasukkan enzim tanase dengan konsentrasi 1\% (v/v) selama 60 menit. Reaksi enzimatik dihentikan dengan menggunakan etanol 95\%.

\section{Isolasi Asam Galat (Belur and Pallabhanvi, 2011)}

Isolasi asam galat dilakukan dengan cara ekstraksi menggunakan etil asetat. Larutan sampel yang telah dihentikan reaksi enzimatiknya, dimasukkan ke dalam corong pisah yang telah diisi larutan etil asetat dengan perbandingan $1: 1$. Campuran selanjutnya dikocok selama 10 menit hingga terbentuk 2 fase larutan. Fase larutan dipisahkan dan pelarutnya dihilangkan menggunakan evaporator pada suhu $75^{\circ} \mathrm{C}$ dan kecepatan $100 \mathrm{rpm}$.

\section{Penentuan Konsentrasi Asam Galat (Vazirian et al., 2011)}

Sebanyak $200 \mu \mathrm{L}$ larutan dimasukkan ke dalam tabung reaksi. Ditambahkan $600 \mu \mathrm{L}$ asam sulfat $(0,2 \mathrm{~N})$. Selanjutnya ke dalam campuran dimasukkan $900 \mu \mathrm{L}$ larutan rodanin $(0,667 \%)$ dan didiamkan selama 9 menit. Setelah 9 menit, ke dalam campuran dimasukkan larutan $\mathrm{KOH}$ 0,5 N dan didiamkan selama 6 menit. Setelah 6 menit, ditambahkan 12,9 mL aquades dan didiamkan selama 25 menit. Absorbansi larutan selanjutnya diukur pada panjang gelombang $520 \mathrm{~nm}$. Larutan blanko dibuat dengan mengganti $900 \mu \mathrm{L}$ larutan rodanin menggunakan $900 \mu \mathrm{L}$ metanol. Larutan standar dibuat dengan 5 variasi konsentrasi asam galat yaitu $4-20 \mu \mathrm{L} / 5 \mathrm{~mL}$.

\section{Penentuan Antioksidan dan Antibakteri}

Sebanyak 2 mL larutan sampel dalam etanol dengan variasi konsentrasi 5, 10, 15, 20 dan $25 \mu \mathrm{g} / \mathrm{mL}$ dicampurkan dengan $2 \mathrm{~mL}$ larutan DPPH 0,002\%, kemudian campuran didiamkan selama 30 menit. Absorbansinya diukur pada $\lambda$ maks $521 \mathrm{~nm}$ dengan menggunakan spektrofotometer UV-Vis. Kekuatan inhibisinya dihitung menggunakan rumus:

$$
\% \text { inhibisi }=\frac{\left(\mathrm{A}_{\text {kontrol }}-\mathrm{A}_{\text {sampel }}\right)}{\mathrm{A}_{\text {kontrol }}} \times 100 \%
$$

Dengan mengalurkan grafik data \% inhibisi versus konsentrasi sampel, dapat ditentukan nilai $\mathrm{IC}_{50}$ melalui regresi linier.

Aktivitas antibakteri sampel diuji menggunakan metode difusi agar pada cakram dish. Biakan E. coli (bakteri gram negatif) dan S. aereus (bakteri gram positif) ditanam sebanyak satu ose pada media padat. Kertas cakram dengan diameter $6 \mathrm{~mm}$ dibasahi dengan asam galat kemudian diinkubasi pada suhu $37{ }^{\circ} \mathrm{C}$ selama 24 jam. Hal yang sama dilakukan juga untuk ekstrak metanol kulit buah lokal. Dilakukan pengamatan terhadap 
zona bening dan sebagai pembanding digunakan amoksisilin dengan konsentrasi 25 $\mathrm{mg} / \mathrm{mL}$. Perhitungan zona hambat dilakukan dengan pengurangan diameter spot dengan diameter kertas cakram.

\section{PEMBAHASAN}

Aktivitas tanase dari A. niger dihasilkan sebesar 57,827 U/mg. Enzim ini digunakan untuk mengkatalis reaksi hidrolisis tanin yang terkandung pada limbah kulit buah lokal selama 60 menit. JumLah asam galat yang dihasilkan dari kulit buah kepundung, juwet dan manggis masing-masing sebesar $4,174 \% ; 2,217 \% ; 1,405 \%(\mathrm{w} / \mathrm{w})$.

Hasil penelitian sebelumnya telah menghasilkan asam galat dari beberapa sumber. Phansawan and Pongsabangpho (2014) menghasilkan asam galat tertinggi pada ekstrak metanol C. alata dan A. paniculata masing-masing sebesar 351,2 $\pm 5,6 \mathrm{mg} / \mathrm{g}$ dan $410 \pm 7,8$ $\mathrm{mg} / \mathrm{g}$. Terminalia chebula dengan kandungan gallotanin sebesar $40 \%$ dapat pula digunakan sebagai bahan baku produksi asam galat (Bhagat et al., 2015).

\section{Aktivitas Antioksidan Asam Galat dan Ekstrak Metanol Kulit Buah}

Kemampuan antioksidan asam galat diuji menggunakan metode DPPH.Hasil penelitian menunjukkan bahwa asam galat yang dihasilkan dari ekstrak metanol kulit buah kepundung, juwet, dan manggis mampu bertindak sebagai antioksidan dengan daya hambat terbesar pada konsentrasi asam galat sebesar $10 \mathrm{ppm}$. Ekstrak metanol kulit buah kepundung dan kulit buah manggis menunjukkan kemampuan yang lebih baik sebagai antioksidan dibandingkan asam galat yang dihasilkan dari ketiga limbah kulit buah yang diuji (Gambar 1).

Berdasarkan data daya hambat yang diuraikan pada Gambar 1, dibuat grafik hubungan antara daya hambat dan konsentrasi sampel untuk menghitung nilai $\mathrm{IC}_{50}$. Hasil penelitian menunjukkan bahwa asam galat yang dihasilkan dari limbah kulit buah kepundung, juwet dan manggis memiliki aktivitas sebagai antioksidan dengan nilai $\mathrm{IC}_{50}$ masing-masing sebesar 5,95; 5,92 dan 5,96 ppm (Tabel 1). Ekstrak metanol kulit buah manggis memiliki $\mathrm{IC}_{50}$ yang lebih kecil dibandingkan semua sampel yaitu sebesar 2,63 ppm. Hasil ini menunjukkan bahwa ekstrak metanol kulit buah manggis memiliki kemampuan yang lebih baik sebagai antioksidan dibandingkan dengan asam galat yang dihasilkan dari ekstrak ketiga kulit buah lokal menggunakan tanase. 


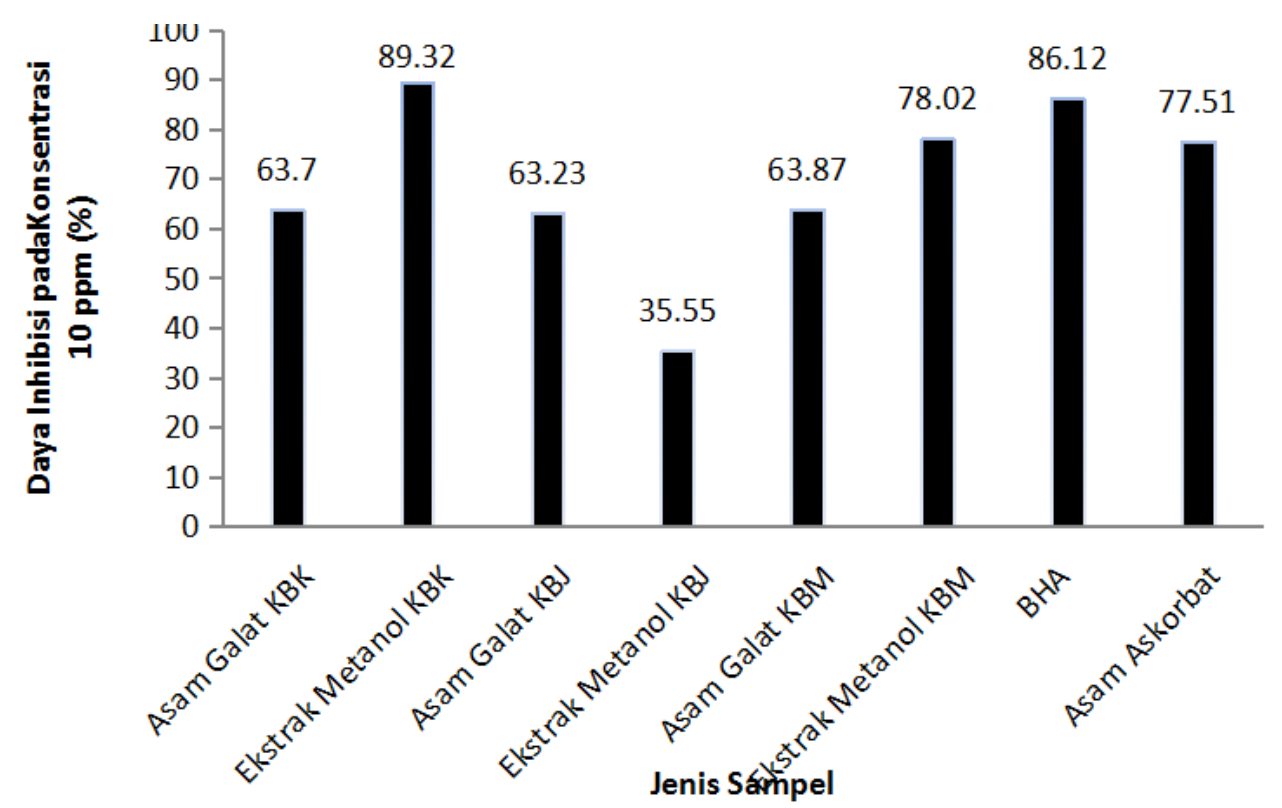

Gambar 1. Daya Inhibisi Sampel (Ket: KBB = Kulit Buah Kepundung; KBJ = Kulit Buah Juwet; KBM = Kulit Buah Manggis)

Tabel 1. Nilai $\mathrm{IC}_{50}$ Sampel

\begin{tabular}{lc}
\hline \multicolumn{1}{c}{ Sampel } & $\mathbf{I C}_{\mathbf{5 0}}(\mathbf{p p m})$ \\
\hline Asam galat dari kulit buah kepundung & 5,95 \\
Ekstrak metanol kulit buah kepundung & 4,38 \\
Asam galat dari kulit buah manggis & 5,92 \\
Ekstrak metanol kulit buah manggis & 2,63 \\
Asam galat dari kulit buah juwet & 5,96 \\
Ekstrak metanol kulit buah juwet & 14,46 \\
BHA & 5,21 \\
Asam Askorbat & 4,98 \\
\hline
\end{tabular}

Aktivitas antioksidan dari ekstrak metanol kulit buah manggis menunjukkan nilai tertinggi dibandingkan sampel lainnya. Penelitian sebelumnya menunjukkan hasil yang berbeda dengan penelitian ini. Palakawong et al. (2010) melaporkan nilai $\mathrm{IC}_{50}$ sebesar 5,94 ppm untuk kulit buah manggis. Perbedaan hasil ini disebabkan oleh penggunaan metode ekstraksi yang berbeda. Palakawong et al. (2010) menggunakan etanol sebagai pelarut dan menghilangkan kandungan tanin melalui pengendapan gelatin. Tachakittirungrod et al. (2007) melaporkan bahwa penggunaan metode ekstraksi yang berbeda dapat mempengaruhi aktivitas antioksidan sampel. Penggunaan jenis pelarut juga dapat mempengaruhi aktivitas antioksidan (Zarena and Sankar, 2009).

Berdasarkan nilai $\mathrm{IC}_{50}$, asam galat yang dihasilkan dari kulit buah pada penelitian ini memiliki aktivitas sebagai antioksidan. Penelitian sebelumnya menunjukkan hal yang serupa dimana Ahmeda et al. (2009) melaporkan bahwa asam galat yang diekstrak dari Phyllanthus niruri menunjukkan persen inhibisi DPPH tertinggi sebesar 80\%. Beberapa buah dengan kandungan asam galat yang tinggi juga dilaporkan memiliki kemampuan 
sebagai antioksidan. Jindal and Mohamad (2012) melaporkan ekstrak metanol buah dan daun Ardisia crispa memiliki $\mathrm{IC}_{50}$ masing-masing sebesar 0,9 dan 1,5 mg/mL. Buah dan kulit buah Baccaurea sapida Muell. Arg memiliki $\mathrm{IC}_{50}$ masing-masing sebesar $2971,7 \mu \mathrm{g} / \mathrm{mL}$ dan 443,31 $\mu \mathrm{g} / \mathrm{mL}$ yang menunjukkan kemampuannya sebagai antioksidan (Wetwitayaklung et al., 2012).

Suatu senyawa memiliki kemampuan sebagai antioksidan dipengaruhi oleh beberapa faktor yaitu jumLah gugus fenol, posisi gugus - $\mathrm{OH}$ dalam senyawa, dan keberadaan gugus fungsional lain (Borra et al., 2013). Struktur asam galat (Gambar 2) memiliki gugus fungsional $-\mathrm{OH}$ yang mampu bereaksi dengan radikal bebas sehingga menghindari proses oksidasi lebih lanjut. Menurut Marino et al. (2014), asam galat mampu bereaksi dengan radikal bebas peroksi dan hidroksiperoksi yang terbentuk dari reaksi oksidasi. Radikal asam galat yang terbentuk distabilkan melalui interaksi dua ikatan hidrogen pada posisi ortho (Badhani et al., 2015).

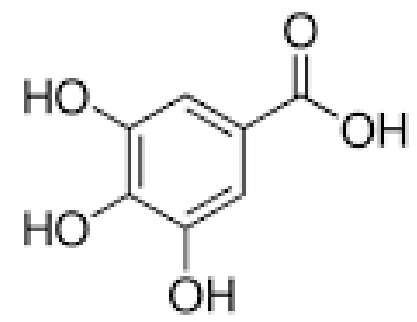

Gambar 2. Struktur Asam Galat

Nilai $\mathrm{IC}_{50}$ pada ekstrak metanol kulit buah kepundung dan kulit buah manggis lebih kecil dibandingkan asam galat menunjukkan kemampuan ekstrak lebih baik sebagai antioksidan dibandingkan asam galat. Hal ini disebabkan masih terkandungnya senyawa selain asam galat pada ekstrak metanol yang memungkinkan efek sinergis sehingga kemampuan sebagai antioksidan lebih kuat. Hajimehdipoor et al. (2014) menemukan keberadaan beberapa senyawa fenol seperti asam galat dan asam kafeat dapat memberikan pengaruh sinergis sebagai antioksidan. Selain itu, keberadaan asam fenolat dan flavonoid dapat meningkatkan aktivitas antioksidan (Brighente et al., 2007).Keberadaan antosianin dan xanton pada kulit buah manggis diduga meningkatkan kemampuannya sebagai antioksidan (Siti Azima et al., 2014; Kosem et al., 2007). Proses asilasi antosianin juga dapat meningkatkan aktivitas antioksidan (Sari et al., 2015).

Berbeda dengan kulit buah kepundung dan kulit buah manggis, kulit buah juwet menunjukkan aktivitas antioksidan yang lebih rendah dibandingkan asam galat. Hal ini kemungkinan disebabkan kandungan senyawa yang bersinergi dengan asam galat pada 
kulit buah juwet terdapat dalam konsentrasi yang kecil dibandingkan kulit buah kepundung dan kulit buah manggis. Kandungan senyawa fenol pada kulit buah juwet diketahui memiliki kandungan terendah dibandingkan kulit buah kepundung dan kulit buah manggis (Junaidi and Anwar, 2015; Azima et al., 2014). Meskipun demikian, kandungan antosianin diperkirakan memiliki peran dalam proses inhibisi radikal bebas (Reginold Jebitta and Jeyanth Allwin, 2016).

Peningkatan aktivitas asam galat sebagai antioksidan dapat dilakukan melalui pembentukan senyawa turunannya atau membentuk senyawa kompleks dengan senyawa lain. Sintesis propil galat sebagai senyawa turunan asam galat diketahui efektif sebagai antioksidan pada makanan (Kasture et al., 2009). Pembentukan kompleks asam galatlesitin dilaporkan mampu bertindak sebagai antioksidan lebih baik dari BHT (Changzhong et al., 2014).

\section{Aktivitas Antibakteri Asam Galat dan Ekstrak Metanol Kulit Buah}

Aktivitas antibakteri asam galat dari kulit buah lokal dilakukan dengan membandingkan zona hambat yang dibentuk sampel dengan zona hambat yang dibentuk oleh amoksisilin. Jika zona hambat yang dibentuk oleh sampel lebih besar daripada zona hambat yang dibentuk oleh amoksisilin, maka sampel efektif sebagai antibakteri. Hasil penelitian menunjukkan bahwa asam galat dari kulit buah lokal dan ekstrak metanol kulit buah lokal resistan terhadap bakteri E. coli dan S. aureus (Tabel 2). Hal ini menunjukkan bahwa asam galat tidak memiliki aktivitas sebagai antibakteri. Penelitian serupa dilaporkan oleh Chung et al. (1993) dan Al Zahrani (2012) yang menemukan bahwa asam galat dan asam ellagat tidak mampu menghambat pertumbuhan bakteri. Penelitian Margaret et al. (2015) melaporkan bahwa ekstrak etanol buah juwet tidak memiliki aktivitas antibaketri baik pada bakteri E. coli dan S. aureus.

Tabel 2..Zona Hambat Asam Galat dan Ekstrak Metanol Kulit Buah Lokal

\begin{tabular}{lcccc}
\hline \multicolumn{2}{c}{ Sampel } & & $\begin{array}{c}\text { Konsentrasi Sampel } \\
(\boldsymbol{\mu g} / \mathbf{m L})\end{array}$ & \multicolumn{2}{c}{ Zona Hambat $(\mathbf{m m})$} \\
\cline { 3 - 5 } & & 25 & $\boldsymbol{S}$. aureus & $\boldsymbol{E}$. coli \\
\hline Asam galat & dari & 50 & Tidak ada & Tidak ada \\
kulit & buah & 75 & Tidak ada & Tidak ada \\
kepundung & & 100 & Tidak ada & Tidak ada \\
& & 25 & $2.3 \pm 0,29$ & $4 \pm 0,5$ \\
\hline Ekstrak & Metanol & 50 & $4 \pm 2,13$ & $4,5 \pm 0,89$ \\
kulit & buah & 75 & $5,5 \pm 1,83$ & $6 \pm 1,16$ \\
kepundung & & 100 & $9 \pm 0,79$ & $7,5 \pm 0,95$ \\
& & & $10,5 \pm 1,12$ & $10 \pm 1,17$ \\
\hline
\end{tabular}




\begin{tabular}{lccc}
\hline \multicolumn{1}{c}{ Sampel } & $\begin{array}{c}\text { Konsentrasi Sampel } \\
(\boldsymbol{\mu g} / \mathbf{m L})\end{array}$ & \multicolumn{2}{c}{ Zona Hambat $(\mathbf{m m})$} \\
\cline { 2 - 4 } & 25 & S. aure $\boldsymbol{c} \boldsymbol{\text { S }}$ & $\boldsymbol{E}$ coli \\
\hline Asam galat dari & 50 & Tidak ada & Tidak ada \\
kulit buah manggis & 75 & Tidak ada & Tidak ada \\
& 100 & Tidak ada & Tidak ada \\
& 25 & $2,5 \pm 0,5$ & $3 \pm 0,65$ \\
\hline Ekstrak metanol & 50 & $2 \pm 0,5$ & Tidak ada \\
kulit buah manggis & 75 & $3 \pm 0,57$ & Tidak ada \\
& 100 & $4 \pm 0,23$ & Tidak ada \\
& 25 & $8 \pm 0,25$ & Tidak ada \\
\hline Asam galat dari & 50 & Tidak ada & Tidak ada \\
kulit buah juwet & 75 & Tidak ada & Tidak ada \\
& 100 & Tidak ada & Tidak ada \\
& 25 & $2 \pm 0,54$ & $3,5 \pm 0,56$ \\
\hline Ekstrak metanol & 50 & Tidak ada & Tidak ada \\
kulit buah juwet & 75 & Tidak ada & Tidak ada \\
& 100 & Tidak ada & Tidak ada \\
& & Tidak ada & Tidak ada \\
\hline Kontrol (Amosisilin $25 \mathrm{mg} / \mathrm{mL})$ & $16,5 \pm 4,32$ & $10,23 \pm 3,23$ \\
\hline
\end{tabular}

Keterangan: Kriteria aktivitas antibakteri sesuai dengan NCCLS (National Committee for Clinical Laboratory Standards), yaitu diameter $0-13 \mathrm{~mm}$ bersifat resisten; $14-17 \mathrm{~mm}$ bersifat intermediate; > $18 \mathrm{~mm}$ bersifat sensitif.

\section{KESIMPULAN}

Asam galat yang dihasilkan dari limbah kulit buah lokal memiliki aktivitas sebagai antioksidan, namun tidak memiliki aktivitas antibakteri. Asam galat dari kulit buah kepundung, kulit buah juwet dan kulit buah manggis memiliki $\mathrm{IC}_{50}$ masing-masing sebesar 5.95; 5,96 dan 5,92 ppm. Aktivitas antioksidan tertinggi dengan nilai $\mathrm{IC}_{50}$ sebesar 2,63 ppm. Asam galat dari ketiga kulit buah lokal resistan terhadap bakteri E. coli dan S. aureus yang menunjukkan bahwa asam galat tidak memiliki aktivitas sebagai antibakteri.

\section{UCAPAN TERIMA KASIH}

Penelitian ini didukung oleh dana penelitian Hibah Bersaing Kemenristek DIKTI tahun 2016.

\section{DAFTAR PUSTAKA}

Ahmeda, A., Hossain, M.A., and Ismail, Z., 2009. Antioxidant Properties of the Isolated Flavonoids from the Medicinal Plant Phyllanthus niruri. Asian Journal of Food and Agro-Industry 2(3), 373-381. 
Al-Zahrani, S.H.M., 2012. Antibacterial Activities of Gallic Acid and Gallic Acid Methyl Ester on Methicillin-Resistant Staphylococcus aureus. Journal of American Science 8(2), 7-12.

Anwar, Y.A.S., and Burhanuddin., 2012. Pengaruh Komposisi Media terhadap Aktivitas dan Karakter Enzim Tanin Asil Hidrolase dari Aspergillus niger. Jurnal Ilmu Kefarmasian Indonesia 10 (2), 87-92.

Anwar, Y.A.S., Artika, I.M., and Danuri, H., 2007. The Production of Tannin Acyl Hydrolase from Aspergillus niger. Mikrobiologi Indonesia 1(2), 91-94.

Badhani, B., Sharma, N., and Kakkar, R., 2015. Gallic Acid: a Versatile Antioxidant with Promising Therapeutic and Industrial Applications. RSC Adv 5, 27540-27557.

Bajpai, B., and Patil, S., 2008. A New Approach to Microbial Production of Gallic Acid. Brazilian Journal of Microbiology 39, 708-711.

Banerjee, D., Debdulal., and Pati, B.R., 2007. Optimization of Tannase Production by Aureobasidium pullulans DBS66. Journal of Microbiology and Biotechnology 17, 1049-1053.

Belur, P.D., and Pallabhanvi, B., 2011. Investigation on Production of Gallic Acid From Terminalia chebula Extract Using Cell Associated Tannase of Bacillus massiliensin. International Conference of Advances in Biotechnology and Pharmaceutical Sciences (ICABPS): Bangkok.

Beniwal, V., Chhokar, V., Singh, N., and Sharma, J., 2010. Optimization of Process Parameters for the Production of Tannase and Gallic Acid by Enterobacter cloacae MTCC 9125. Journal of American Science 6(8), 389-397.

Bhagat, S., Dongre, P., Bhagat, S., and Dikpati, A., 2015. Extraction and Isolation of Gallic Acid from Self-Generated Fermentation System of Terminalia chebula. Journal of Chemical and Pharmaceutical Research 7(4), 170-174.

Borra, S.K., Gurumurthy, P., Mahendra, J., K.M. Jayamathi, C.N. Cherian, and Chand, R., 2013. Antioxidant and Free Radical Scavenging Activity of Curcumin Determined by Using Different in Vitro and ex Vivo Models. Journal of Medicinal Plants Research 7(36), 2680-2690.

Brighente, I.M.C., Dias, M., Verdi, L.G., and Pizzolatti, M.G., 2007. Antioxidant Activity and Total Phenolic Content of Some Brazilian Species. Pharmaceutical Biology $45(2), 156-161$.

Chia, Y-C., Rajbanshi, R., Calhoun, C., and Chiu, R.H., 2010. Anti-Neoplastic Effects of Gallic Acid a Major Component of Toona Sinensis Leaf Extract on Oral Squanous Carcinoma Cell. Molecules 15, 8377-8389.

Changzhong, L., Chen, C., Mo H, Ma H, Yuan E, and Li Q., 2014. Characterization and DPPH Radical Scavenging Activity of Gallic Acid-Lecithin Complex. Tropical Journal of Pharmaceutical Research 13(8), 1333-1338.

Chung, K.T., Stevens, S.E., Lin, W.F., and Wei, C.I., 1993. Growth Inhibition of Selected Food-Borne Bacteria by Tannic Acid, Propyl Gallate and Related Compounds. Letter in Applied Microbiology 17, 29-32.

Gaffar, R., Sazali, N.E.S., and Abdul Majid, F.A., 2008. Colour Reduction and AntiMicrobial Evaluation of Pre-Treated Cashew Leaves Extract. Journal of Chemical 
and Natural Resources Engineering - Sustainable Process for Natural Resources $2,1-9$.

Hagerman, A.E., 2002. Tannin Chemistry. http://www.users.muohio .edu/ hagermae / tanin.pdf (diakses pada 9 Juli 2016).

Hajimehdipoor, H., Shahrestani, R., and Shekarchi, M., 2014. Investigating the Synergistic Antioxidant Effects of Some Flavonoid and Phenolic Compounds. Research Journal of Pharmacognosy 1(3), 35-40.

Iqbal, H., and Kapoor, A., 2012. Culture conditions for the production of tannase from Tricoderma harzianum MTCC 10841. International Journal of Science and Technology 1(2), 584-595.

Jindal, H.M.K., and Mohamad, J., 2012. Antioxidant Activity of Ardisia Crispa (Mata Pelanduk). Sains Malaysiana 41(5), 539-545.

Junaidi, E., and Anwar, Y.A.S., 2015. Produksi Asam Galat dari Limbah Buah Lokal Di Pulau Lombok secara Enzimatis. Laporan Penelitian Hibah Bersaing Kemenristek.

Kasture, V.S., Katti, S.A., Mahajan, D., Wagh, R., Mohan, M., and Kasture, S.B., 2009. Antioxidant and Antiparkison Activity of Gallic Acid Derivatives. Pharmacologyonline 1, 385-395.

Kosem, N., Han,Y-H., and Moongkarndi, P., 2007. Antioxidant and Cytoprotective Activities of Metanolic Extract from Garcinia mangostana Hulls. Science Asia 33, 283-292.

Lokeswari, N., and Kumar, B.L., 2013. A Novel Biochemical Method for Production of an Antibacterial Drug Trimethoprim from Industrial Wastes. International Journal of Pharmacy and Pharmaceutical Sciences 5(3), 651-653.

Margaret, E., Shailaja, A.M., and Venugopal Rao, V., 2015. Evaluation of Antioxidant Activity in Different Parts of Syzygium cumini (Linn.). International Journal of Current Microbiology and Applied Sciences 4(9), 372-379.

Marino, T., Galano, A., and Russo, N., 2014. Radical Scavenging Ability of Gallic Acid Toward $\mathrm{OH}$ and $\mathrm{OOH}$ Radicals: Reaction Mechanism and Rate Constants from the Density Functional Theory. The Journal of Physical Chemistry B 118(35), 10380-10389.

Nutan et al., 2013. Ellagic Acid and Gallic Acid from Lagestroemia speciosa L. Inhibit HIV-1 Infection through Inhibition of HIV-1 Protease and Reverse Transcriptase Activity. Indian Journal of Medical Research 137, 540-548.

Palakawong, C., Sophanodora, P., Pisuchpen, S., and Phongpaichit, S., 2010. Antioxidant and Antimicrobial Activities of Crude Extracts from Mangosteen (Garcinia mangostana L) Parts and Some Essential Oils. International Food Research Journal 17, 583-589.

Pedraza-Chaverri, J., Cardenas-Rodriguez, N., Orozco-Ibarra, M., and Perez-Rojas, J.M., 2008. Medicinal Properties of Mangosteen (Garcinia mangostana). Food and Chemical Toxicology 46, 3227- 3239.

Phansawan, B., and Pongsabangpho, S., 2014. Determination of Gallic Acid and Rutin in Extracts Cassia alata and Andrographis paniculata. Science Asia 40, 414-419. 
Reginold Jebitta, S., and Jeyanth Allwin, S., 2016. Antioxidant Activity, Total Phenol, Flavonoid, and Anthocyanin Contents of Jamun (Syzygium Cumini) Pulp Powder. Asian Journal of Pharmaceutical and Clinical Research 9(2), 361-363.

Sari, P., Setiawan, A., and Siswoyo, T.A., 2015. Stability and Antioxidant Activity of Acylated Jambolan (Syzygiuoloum cumini) Anthocyanins Synthesized by LipaseCatalyzed Transesterification. International Food Research Journal 22(2), 671676.

Siti Azima, A.M., Noriham, A., and Manshoor, N., 2014. Anthocyanin Content in Relation to the Antioxidant Activity and Colour Properties of Garcinia mangostana Peel, Syzigium cumini and Clitoria ternatea Extracts. International Food Research Journal 21(6), $2369-2375$.

Tachakittirungrod, S., Okonogi, S., and Chowwanapoonpohn, S., 2007. Study on Antioxidant Activity of Certain Plants in Thailand: Mechanism of Antioxidant Action of Guava Leaf Extract. Food Chemistry 103, 381-388.

Vazirian, M., Khanavi, M., Amanzadeh, Y., and Hajimehdipoor, H., 2011. Quantification of Gallic Acid in Fruits of Three Medicinal Plants. Iranian Journal of Pharmaceutical Research 10(2), 233-236.

Wetwitayaklung, P., Charoenteeraboon, J., Limmatvapirat, C., and Phaechamud, T., 2012. Antioxidant Activities of Some Thai and Exotic Fruits Cultivated in Thailand. Research Journal of Pharmaceutical, Biological and Chemical Sciences 3(1), 1221.

Zarena, A.S., and Sankar, K.U., 2009. A Study of Antioxidant Properties from Garzinia Mangostana L. Pericarp Extract. Acta Scientiarum Polonorum Technologia Alimentaria 8(1), 23-34. 